\title{
EFEKTIFITAS MEKANISME BONDING DIVIDEN DAN HUTANG UNTUK MENGURANGI MASALAH AGENSI PADA PERUSAHAAN DI BURSA EFEK JAKARTA
}

\author{
Zaenal Arifin \\ Fakultas Ekonomi \\ Universitas Islam Indonesia
}

\begin{abstract}
Jensen (1986) said that the agency problem can be minimized by reducing the free cash flows in a company. These free cash flows can be reduced by increasing the debt or by increasing the dividend. This theory was developed in the United State of America in which most of the listed companies have a dispersed ownership structure. It is interesting to evaluate the effectiveness of this bonding mechanism for the listed companies in Jakarta Stock Exchange in which most of them have a concentrated ownership structure. The purpose of this research is to examine the effectiveness of this bonding mechanism.

By investigating the same sample of listed companies in Jakarta Stock Exchange in 1996 and in 2000, this research discovers that in 1996, the debt bonding mechanism is not effective to reduce an agency problem but it increases the agency problem instead. In 2000, the debt bonding mechanism is still not effective but it does not increase the agency problem anymore. Meanwhile, the dividend bonding mechanism is effective to reduce the agency problem both in 1996 and in 2000. However, the dividend bonding mechanism is avoided by the companies that have a family ownership that closed to a minimum portion of majority or domination.
\end{abstract}

Kata Kunci: Agency Problem, Bonding, Hutang, Dividen, Kepemilikan Keluarga

\section{PENDAHULUAN}

Kurniawan dan Indriantoro (2000) menilai pelaksanaan corporate governance di Indonesia belum baik. Salah satu faktor yang mereka identifikasi sebagai penyebabnya adalah struktur kepemilikan perusahaanperusahaan publik di Indonesia terlalu didominasi oleh keluarga, sehingga perlindungan terhadap investor kecil menjadi lemah. Pada saat yang sama fungsi dewan komisaris dalam membawa aspirasi/kepentingan pemegang saham non-mayoritas juga masih lemah. Akibatnya, masalah agensi sering muncul antara manajemen dan keluarga di satu pihak dan investor nonkeluarga di pihak yang lain.

Banyak mekanisme yang dapat diupayakan untuk mengurangi masalah agensi. Jensen dan Meckling (1976) mengidentifikasi ada dua tipe mekanisme yaitu mekanisme monitoring dan mekanisme bonding. Mekanisme pertama dilakukan oleh pihak di luar manajemen seperti dewan komisaris, pasar corporate control, pasar manajer, dan investor besar, sedangkan mekanisme kedua dilakukan sendiri oleh pihak manajemen 
dengan memberikan sinyal-sinyal yang menunjukkan bahwa probabilitas mereka melakukan tindakan yang menimbulkan masalah agensi menjadi kecil.

Jensen (1986) mengemukakan bahwa mekanisme bonding yang dapat dipakai manajemen untuk menunjukkan bahwa mereka berusaha memperkecil masalah agensi adalah dengan membuat keputusankeputusan yang berakibat memperkecil jumlah free cash flows yang ada di perusahaan. Dengan free cash flows yang kecil manajemen tidak mempunyai banyak peluang menggunakan dana untuk kepentingan pribadi yang bertentangan dengan peningkatan nilai perusahaan. Dengan kata lain masalah agensi akan semakin berkurang ketika free cash flows semakin kecil.

Ada dua cara yang dapat dipakai untuk memperkecil free cash flows yaitu meningkatkan hutang dan meningkatkan dividen. Ketika hutang meningkat maka manajer harus menyisihkan dana yang lebih besar untuk membayar angsuran maupun bunga hutang sehingga dana yang tersisa menjadi kecil. Sedangkan ketika dividen meningkat maka secara otomatis dana tunai perusahaan langsung berkurang sebesar peningkatan dividen tersebut.

Penelitian ini ingin mengetahui apakah mekanisme bonding dengan meningkatkan hutang atau meningkatkan dividen ini dapat efektif untuk mengurangi masalah agensi pada perusahaan publik di Indonesia. Jensen (1986) menyusun teori agensi-nya dalam konteks perusahaanperusahaan publik di Amerika Serikat. Padahal struktur kepemilikan perusahaan publik di Indonesia berbeda dengan struktur kepemilikan perusahaan publik di Amerika Serikat; di Indonesia struktur kepemilikan perusahaannya terkonsentrasi pada keluarga (lihat misal Claessens et al, 2000) sedangkan di Amerika Serikat struktur kepemilikan perusahaannya menyebar (lihat misal Barle dan Means, 1932). Perbedaan struktur kepemilikan ini menyebabkan akar masalah agensi di perusahaan publik Indonesia berbeda dengan akar masalah agensi perusahaan publik di Amerika Serikat. Di Indonesia, masalah agensinya adalah antara pemilik keluarga bersama manajemen dan pemilik non keluarga sedangkan di Amerika Serikat masalah agensinya antara manajemen dan seluruh pemegang saham perusahaan. Pertanyaannya adalah apakah teori agensinya Jensen ini juga efektif untuk mengurangi masalah agensi di Indonesia meskipun akar masalah agensi di Indonesia berbeda dengan konteks yang dijadikan landasan penyusunan teori tersebut.

\section{HUTANG, DIVIDEN, DAN MASALAH AGENSI}

Sebelum Jensen (1986), Jensen dan Meckling (1976) sebenarnya juga sudah mengemukakan bahwa kenaikan hutang dapat digunakan untuk mengurangi masalah agensi namun bukan dengan alasan untuk 
memperkecil free cash flows. Mereka menyatakan bahwa kenaikan hutang akan mengurangi masalah agensi karena dengan kenaikan hutang maka outside equity tidak akan bertambah. Ketika outside equity tidak meningkat maka konflik antara manajemen dan pemegang saham juga tidak meningkat. Sementara itu, Rozeff (1982) juga sudah mengemukakan bahwa kenaikan dividen dapat digunakan untuk mengurangi masalah agensi. Ketika dividen naik, probabilitas perusahaan mengambil dana dari luar (bukan dana internal) akan meningkat. Ketika perusahaan sering melakukan pengambilan dana dari luar, baik dengan cara menerbitkan saham baru maupun dengan menambah hutang baru, perusahaan akan lebih sering dimonitor kinerjanya oleh calon investor sehingga masalah agensi di perusahaan tersebut akan berkurang.

Uji empiris tentang pengaruh kenaikan hutang terhadap nilai perusahaan di Amerika Serikat banyak yang mendukung teori agensi (lihat misal review penelitian tentang struktur modal oleh Haris dan Raviv (1991)). Sementara itu uji empiris tentang pengaruh kenaikan dividen terhadap nilai perusahaan beragam, ada yang positif dan ada yang negatif (lihat misal Copeland dan Weston (1992)). Bagimana kemungkinan hasil uji empiris di perusahaan dengan struktur terkonsentrasi pada keluarga?

McConaughy et al (2001) menemukan bahwa perusahaan yang dikontrol keluarga cenderung menggunakan hutang yang lebih kecil dibandingkan dengan perusahaan yang dikontrol oleh manajemen profesional. Nampaknya keluarga lebih sensitive (risk averse) terhadap hutang dibandingkan dengan manajer. Lebih konservatifnya keluarga ini kemungkinan disebabkan oleh kecenderungan bahwa keluarga menggunakan perspektif yang lebih panjang dalam pengelolaan perusahaan dibandingkan dengan manajer seperti dikemukakan oleh Kets de Vries (1993). Karena keluarga lebih berkeberatan untuk meningkatkan hutang maka mekanisme bonding dengan meningkatkan hutang diperkirakan justru lebih efektif untuk mengurangi masalah agensi pada perusahaan yang dikontrol keluarga. Sehingga hipotesis yang diajukan berkaitan dengan bonding hutang adalah:

H1 : Peningkatan hutang lebih efektif untuk mengurangi masalah agensi pada perusahaan yang dikontrol oleh keluarga dibandingkan dengan pada perusahaan yang dikontrol oleh bukan keluarga.

Keputusan menaikkan dividen akan mengurangi dana internal yang dimiliki perusahaan untuk keperluan peningkatan modal kerja maupun ekspansi. Ketika dana internal tidak mencukupi untuk keperluan peningkatan modal kerja dan ekspansi, perusahaan terpaksa menutupnya dengan mengambil hutang atau menerbitkan saham baru. Mengambil 
hutang baru, seperti diuraikan di atas, cenderung kurang disukai oleh keluarga yang memang cenderung memiliki sifat konservatif. Peningkatan dividen ini lebih memberatkan keluarga karena peningkatan dividen secara tidak langsung akan memaksa perusahaan meningkatkan jumlah hutangnya. Efek ini membuat peningkatan dividen lebih mengekang manajemen yang dikuasai keluarga sehingga peningkatan dividen diperkirakan lebih efektif untuk mengurangi masalah agensi pada perusahaan yang dikontrol keluarga. Berdasarkan hal tersebut hipotesis yang diajukan berkaitan dengan bonding dividen adalah:

H2 : Peningkatan dividen lebih efektif untuk mengurangi masalah agensi pada perusahaan yang dikontrol oleh keluarga dibandingkan dengan pada perusahaan yang dikontrol oleh bukan keluarga.

Sementara itu, menerbitkan saham baru juga dapat mempengaruhi daya kontrol keluarga terhadap perusahaan. Bahkan ketika porsi kepemilikan keluarga mendekati batas minimum mayoritas (mendekati porsi 50\%) atau batas minimum dominasi (mendekati porsi 20\% atau 10\%), menerbitkan saham baru dapat menghilangkan hak kontrol mayoritas atau dominasi yang selama ini mereka miliki. Oleh karena itu, meskipun bonding dengan meningkatkan dividen ini dapat menjadi sinyal yang efektif untuk menunjukkan bahwa manajemen merupakan agen yang baik, mekanisme ini cenderung dihindari ketika kepemilikan keluarga mendekati batas minimum mayoritas atau dominasi. Hipotesis yang diajukan berkaitan dengan hal ini adalah:

H3 : Perusahaan yang dikontrol oleh keluarga cenderung menghindari bonding peningkatan dividen ketika porsi kepemilikannya mendekati batas minimum mayoritas atau minimum dominasi.

\section{SAMPEL DAN OPERASIONALISASI VARIABEL}

Perusahaan yang dianalisis dalam penelitian ini adalah seluruh perusahaan yang listing di Bursa Efek Jakarta (BEJ) pada awal tahun 1996 dan tetap bertahan sampai dengan akhir tahun 2000. Penelitian ini akan membandingkan perbedaan efektifitas bonding pada kedua tahun yang masing-masing mewakili tahun sebelum terjadi krisis ekonomi dan tahun setelah terjadi krisis ekonomi. Pada awal tahun 1996 terdapat 238 perusahaan yang listing di BEJ dan dari perusahaan tersebut yang masih bertahan hingga akhir tahun 2000 ada 213 perusahaan sehingga jumlah yang terakhir inilah yang akan dianalisis. 
Penelitian ini memakai dua definisi keluarga: Pertama, Keluarga (1), dimana keluarga adalah seluruh individu dan perusahaan yang kepemilikannya wajib tercatat (minimum 5\%) kecuali dia adalah perusahaan publik, negara, institusi keuangan, atau perusahaan asing. Kedua, Keluarga (2), dimana keluarga adalah satu individu atau perusahaan dengan porsi kepemilikan tertinggi dan kepemilikannya wajib tercatat kecuali dia adalah perusahaan publik, negara, institusi keuangan, atau perusahaan asing. Definisi pertama mengasumsikan individu dan perusahaan yang tercatat memiliki keterkaitan keluarga atau kroni baik langsung maupun tidak langsung sedangkan definisi kedua, sebaliknya, berasumsi antar individu dan perusahaan tersebut tidak ada hubungan keluarga.

Untuk mengukur efektifitas pengurangan masalah agensi digunakan cumulative abnormal return (CAR) mingguan selama satu tahun. Perusahaan yang lebih baik pengurangan masalah agensinya dibandingkan perusahaan lain akan memiliki kinerja yang juga lebih baik, dimana kinerja dalam penelitian ini di-proxy dengan CAR. Dengan demikian, semakin besar pengurangan masalah agensi di suatu perusahaan maka semakin besar CAR perusahaan tersebut. CAR yang dihitung dari abnormal return mingguan perusahaan terhadap return pasar dapat mengakomodasi kebutuhan alat ukur kinerja yang bersifat relatif seperti ini. Dalam penelitian ini dipakai dua definisi cumulative abnormal return yaitu: (1) yang tidak disesuaikan dengan dividen (CAR) dan (2) yang disesuaikan dengan dividen (CARAdj).

\section{EFEKTIFITAS BONDING HUTANG DAN DIVIDEN}

Uji efektifitas bonding hutang dan dividen dilakukan dalam satu persamaan regresi yang bentuk dasarnya sebagai berikut:

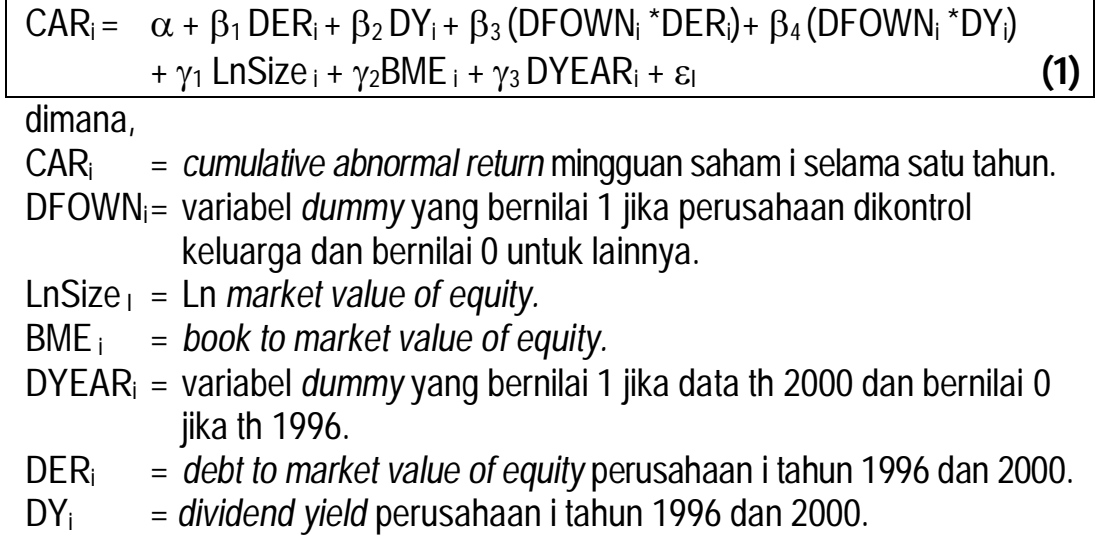


Pertama-tama, model dasar ini diuji apakah ada kesalahan spesifikasi atau tidak dengan Ramsey Regression Specification Error Test. Ternyata hasil ujinya menunjukkan bahwa persamaan (1) mengalami kesalahan spesifikasi atas pola pengaruh size yang dimodelkan linier ternyata berpola parabolic sehingga perlu ditambah variabel LnSize ${ }^{\wedge}$. Langkah berikutnya adalah melakukan uji dengan Forward Method untuk mengetahui apakah ada variabel interaksi antara variabel utama dengan variabel dummy tahun yang signifikan koefisiennya (batas atas Prob. Value 20\%). Hasil uji menunjukkan bahwa koefisien variabel DYEAR*DER signifikan untuk dimasukkan dalam model.

Dalam model uji efektifitas bonding tersebut dimasukkan dua variabel kontrol yaitu size dan book to market value of equity (BME). Size dijadikan variabel kontrol karena banyak penelitian sebelumnya menemukan size berpengaruh signifikan terhadap return (misal Kim et al (1988), Crutchley dan Hansen (1989), Volpin (2002), dan Mitton (2002)). Sementara itu Fama dan French (1992) menambahkan BME sebagai varaibel yang juga signifikan mempengaruhi return.

Model dasar yang sudah ditambah dengan variabel $\operatorname{LnSize}^{\wedge} 2$ dan DYEAR*DER kemudian dilakukan uji heteroskedastisitas dengan White Heteroskedasticity Test dan uji autokorelasi dengan Ljung-Box Q-Statistic Test. Hasil uji menunjukkan bahwa model tersebut mengalami masalah heteroskedastisitas yang signifikan dan khusus untuk model yang memakai variabel dependen CARADJ juga mengalami masalah autokorelasi yang signifikan. Karena muncul masalah heteroskedastisitas pada model dengan variabel dependen CAR maka koefisien yang dipakai bukan koefisien hasil perhitungan ordinary least square (OLS) melainkan memakai koefisien hasil perhitungan White Heteroskeadisticity-Consistent Standard Errors \& Covariance. Sedangkan model dengan dependen variabel CARADJ yang mengalami masalah heteroskedastisitas dan autokorelasi memakai koefisien hasil perhitungan Newey-West HAC Standard Errors \& Covariance. Hasil uji efektifitas bonding dengan model tersebut ditampilkan dalam Tabel 1 di bawah ini.

Dari Tabel 1 nampak bahwa hasil untuk empat model (dua versi dependen variebel dan dua versi definisi keluarga) cenderung sama. Koefisien DER yang signifikan negatif dapat diinterpretasikan bahwa pada tahun 1996, kenaikan hutang secara umum tidak hanya tidak efektif untuk mengurangi masalah agensi namun justru meningkatkan masalah agensi. Temuan yang bertentangan dengan teori agensi ini kemungkinan karena banyak hutang perusahaan yang berasal dari bank yang kepemilikannya sama dengan pemilik perusahaan. Karena hutang berasal dari bank yang satu kelompok kepemilikan maka kontrol terhadap kelayakan kredit dan monitoring penggunaan dana kredit menjadi lemah. 
Tabel 1: Hasil Uji Efektifitas Bonding Hutang dan Dividen

\begin{tabular}{|c|r|r|r|r|r|r|r|r|}
\hline & \multicolumn{4}{|c|}{ Dep. Var: CAR } & \multicolumn{3}{c|}{ Dep. Var.: CARADJ } \\
\hline & Keluarga(1) & \multicolumn{2}{|c|}{ Keluarga (2) } & \multicolumn{2}{|c|}{ Keluarga (1) } & \multicolumn{2}{c|}{ Keluarga (2) } \\
\hline Var & Koef & Prob & Koef & Prob & Koef & Prob & Koef & Prob \\
\hline C & -1.7215 & 0.070 & -1.8069 & 0.057 & -1.5102 & 0.103 & -1.5921 & 0.084 \\
\hline DER & -0.0512 & $\mathbf{0 . 0 4 6}$ & -0.0442 & $\mathbf{0 . 0 8 3}$ & -0.0513 & $\mathbf{0 . 0 3 7}$ & -0.0447 & $\mathbf{0 . 0 6 8}$ \\
\hline DY & 1.9679 & $\mathbf{0 . 0 6 8}$ & 1.9383 & $\mathbf{0 . 0 6 6}$ & 2.7173 & $\mathbf{0 . 0 1 9}$ & 2.7062 & $\mathbf{0 . 0 1 6}$ \\
\hline DFOWN*DER & 0.0527 & $\mathbf{0 . 0 3 5}$ & 0.0491 & $\mathbf{0 . 0 5 3}$ & 0.0505 & $\mathbf{0 . 0 2 6}$ & 0.0474 & $\mathbf{0 . 0 4 2}$ \\
\hline DFOWN*DY & 0.7297 & 0.612 & 0.5893 & 0.685 & 0.8043 & 0.600 & 0.6271 & 0.676 \\
\hline LSIZE & 0.3187 & 0.038 & 0.3331 & 0.031 & 0.2837 & 0.062 & 0.2975 & 0.049 \\
\hline LSIZE^2 & -0.0156 & 0.010 & -0.0162 & 0.008 & -0.0142 & 0.021 & -0.0147 & 0.015 \\
\hline BME & 0.0059 & 0.033 & 0.0059 & 0.034 & 0.0056 & 0.074 & 0.0056 & 0.075 \\
\hline DYEAR & -0.0281 & 0.694 & -0.0190 & 0.788 & -0.1477 & 0.058 & -0.1391 & 0.071 \\
\hline DYEAR*DER & 0.0442 & $\mathbf{0 . 0 9 1}$ & 0.0383 & 0.143 & 0.0442 & 0.110 & 0.0385 & 0.159 \\
\hline
\end{tabular}

Keterangan: Model dengan dependent variable CAR memakai koefisien hasil perhitungan White Heteroskedasticity - Consistent Standard Errors \& Covariance sedangkan model dengan dependent variable CARADJ memakai Newey-West HAC Standard Errors \& Covariance

Dari Tabel 1 juga nampak bahwa koefisien DFOWN*DER signifikan positif. Hal ini menunjukkan bahwa efek negatif berupa peningkatan hutang cenderung dapat dinetralisir jika perusahaan tersebut dikontrol keluarga. Kontrol keluarga meskipun belum dapat membuat bonding hutang menjadi efektif namun kontrol tersebut sudah dapat menghilangkan efek negatif dari kenaikan hutang. Sementara itu positifnya koefisien DYEAR*DER menunjukkan bahwa pada tahun 2000, efek negatif kenaikan hutang sudah sangat berkurang bahkan pada perusahaan yang dikontrol keluarga pengaruh hutang sudah berubah menjadi positif untuk mengurangi masalah agensi meskipun masih tetap belum signifikan efektif untuk mengurangi masalah agensi.

Dari Tabel 1 juga nampak bahwa koefisien DY signifikan positif. Ini menunjukkan bahwa secara umum kenaikan dividen efektif untuk mengurangi masalah agensi pada perusahaan publik di Indonesia baik pada tahun 1996 maupun pada tahun 2000. Tidak masuknya variabel DYEAR ${ }^{*}$ DY dalam model berdasarkan analisis Forward Method membuktikan tidak adanya perbedaan pola dan intensitas pengaruh kenaikan dividen terhadap pengurangan masalah agensi antara tahun 1996 dan tahun 2000. Sementara itu nilai koefisien DFOWN*DY yang positif namun tidak signifikan menunjukkan bahwa bonding dengan menaikkan dividen pada perusahaan yang dikontrol keluarga lebih efektif dibandingkan pada perusahaan yang tidak dikontrol keluarga namun perbedaan tingkat efektifitasnya tidak signifikan. 
Dari Tabel 1 nampak bahwa koefisien DYEAR untuk model dengan variabel dependen CAR adalah negatif tidak signifikan sedangkan untuk model dengan variabel dependen CARADJ adalah negatif signifikan. Temuan ini menunjukkan bahwa telah terjadi penurunan cumulative abnormal return pada tahun 2000 dibandingkan dengan pada tahun 1996 dan penurunan tersebut besarnya signifikan untuk cumulative abnormal return yang memasukkan dividen. Sementara itu dua variabel kontrol, size dan BME, juga terbukti berpengaruh signifikan terhadap CAR maupun CARADJ dan pola pengaruhnya tidak berbeda antara tahun 1996 dan tahun 2000. Ukuran perusahaan memiliki pengaruh yang bersifat parabolic. Ketika ukuran perusahaan relatif kecil peningkatan ukuran perusahaan akan meningkatkan cumulative abnormal return, namun pada ukuran tertentu, peningkatan ukuran perusahaan justru akan mengurangi cumulative abnormal return. Temuan ini menunjukkan bahwa perusahaan yang relatif lebih kecil ukurannya cenderung lebih baik kinerjanya. Sedangkan variable kontrol yang kedua, BME, berpengaruh positif terhadap CAR. BME membandingkan nilai buku dan nilai pasar ekuitas. Ketika pasar menilai relatif rendah maka BME akan tinggi dan sebaliknya ketika pasar menilai relatif tinggi maka BME menjadi rendah. Dengan demikian hubungan positif antara BME dan CAR menunjukkan bahwa ketika semakin rendah penilaian pasar atas ekuitas perusahaan (undervalued) maka probabilitas perusahaan untuk memperoleh CAR yang tinggi akan semakin besar.

\section{BONDING DIVIDEN DAN UPAYA MEMPERTAHANKAN KONTROL}

Hipotesis 3 menyatakan bahwa perusahaan yang dikontrol keluarga cenderung menghindari bonding peningkatan dividen ketika porsi kepemilikannya mendekati batas minimum mayoritas atau minimum dominasi. Uji empiris terhadap hipotesis ini menggunakan model logit seperti persamaan berikut ini.



dimana,

$P \quad=$ probabilitas.

$Y_{i}=1$, yaitu dividen perusahaan i naik dari tahun 1995/1999 ke 1996/2000.

$\mathrm{Y}_{\mathrm{i}} \quad=0$ jika dividen per share-nya tetap atau turun

DFCONT $_{i}=$ variable dummy dengan nilai 1 jika kepemilikan keluarga di perusahaan i ada pada kisaran $50.00-55.00 \%$ atau 20.00- 


$$
\begin{aligned}
& 25.00 \% \text { atau } 10.00-15.00 \% \text { dan nilai } 0 \text { untuk besar } \\
& \text { kepemilikan keluarga lainnya. } \\
\Delta \text { EPS }_{\mathrm{i}}= & \text { perubahan earning per share perusahaan } \mathrm{i} \text { dari tahun } \\
& 1995 / 1999 \text { ke tahun } 1996 / 2000 . \\
\mathrm{EPS}_{\mathrm{i}}= & \text { earning per share perusahaan i pada tahun } 1996 \text { dan } 2000 \\
\text { DIVLALU }_{\mathrm{i},}= & \text { dividen perusahaan i pada tahun sebelumnya (1995 dan 1999) } \\
& \text { Koefisien model logit tersebut diestimasi dengan Maximum } \\
& \text { Likelihood Estimator (MLE) yang rumusnya sebagai berikut: }
\end{aligned}
$$

$L=\Pi^{n} F\left(\beta^{\prime} x_{i}\right) y_{i}\left[1-F\left(\beta^{\prime} x_{i}\right)\right]^{1-y i}$.

dimana,

$$
\begin{array}{ll}
F\left(\beta^{\prime} x_{i}\right)= & e^{\beta^{\prime} x i}\left(1+e^{\beta^{\prime} x i}\right)^{-1} . \\
\beta & =\text { koefisien persamaan. } \\
e & =\text { bilangan epsilon. } \\
x_{i} & =\text { independent variables. } \\
y_{i} & =\text { dependent variable. } \\
n & =\text { jumlah sampel. }
\end{array}
$$

Dengan menggunakan metode iterative Newton-Raphson akan diperoleh MLE. Metode Newton-Rhapson menggunakan formula sebagai berikut:

$\beta_{n+1}=\beta_{n}-\left(\partial^{2} \log L / \partial \beta_{n} \partial \beta_{n}^{\prime}\right)^{-1} \partial \log L / \partial \beta_{n}$

Berdasarkan hipotesis 3 diprediksi variabel DFCONT berpengaruh negatif signifikan terhadap probabilitas kenaikan dividen. Perusahaan yang porsi kepemilikan keluarganya pada kisaran tersebut, probabilitas kenaikan dividennya lebih kecil dibandingkan dengan yang kepemilikannya di luar kisaran itu. Dengan kata lain, perusahaan akan menghindari bonding dividen pada saat kepemilikannya mendekati batas minimum mayoritas atau minimum dominasi. Hasil uji empiris hipotesis 3 dengan memakai dua definisi keluarga dimuat dalam Table 2 di bawah ini.

Dari Tabel 2 terlihat bahwa koefisien DFCONT negatif signifikan untuk model yang memakai definisi keluarga (2) dan negatif namun tidak signifikan untuk model yang memakai definisi keluarga (1). Temuan ini menunjukkan bahwa perusahaan yang kepemilikan keluarganya mendekati batas minimum memang cenderung menghindari bonding dengan cara menaikkan dividen meskipun tingkat penghindarannya ketika memakai definisi keluarga (2) signifikan sedangkan ketika memakai definisi keluarga (1) tidak signifikan. 
Tabel 2: Hasil Uji Penghindaran Bonding Dividen pada Porsi Kepemilikan Keluarga Mendekati Batas Minimum Mayoritas/Dominasi

\begin{tabular}{|c|r|r|r|r|}
\hline Var & \multicolumn{2}{|c|}{ Keluarga (1) } & \multicolumn{2}{c|}{ Keluarga (2) } \\
\hline & Koef & Prob & Koef & Prob \\
\hline C & -2.2214 & 0.000 & -2.1413 & 0.000 \\
\hline DFCONT & -0.6067 & 0.225 & -0.9093 & $\mathbf{0 . 0 4 8}$ \\
\hline DEPS & -0.0013 & 0.000 & -0.0013 & 0.000 \\
\hline EPS & 0.0019 & 0.000 & 0.0020 & 0.000 \\
\hline DIVLALU & -0.0060 & 0.000 & -0.0062 & 0.000 \\
\hline DYEAR & 0.8431 & 0.005 & 0.8342 & 0.006 \\
\hline
\end{tabular}

Perbedaan tingkat penghindaran ini dapat dimengerti karena definisi keluarga (1) mendefinisikan keluarga sebagai total keseluruhan individu dan perusahaan sedangkan definisi keluarga (2) mendefinisikan keluarga hanya satu individu atau perusahaan yang terbesar kepemilikannya. Perbedaan ini membuat batasan 'kepemilikan mendekati batas minimum mayoritas/dominasi' akan lebih jelas pada definisi keluarga (2) dari pada definisi keluarga (1). Pada definisi keluarga (1), jika ternyata ada salah satu saja dari komponen kepemilikan keluarga yang ternyata tidak ada kaitan hubungan dengan komponen keluarga yang lain maka batasan tersebut menjadi kabur.

Pola penghindaran bonding dividen ini tidak berbeda antara tahun 1996 dan tahun 2000 (Forward Method tidak memasukkan variabel DYEAR ${ }^{\star}$ DFCONT ke dalam model). Signifikan positifnya koefisien variabel DYEAR menunjukkan bahwa probabilitas kenaikan dividen pada tahun 2000 lebih besar dibandingkan dengan probabilitasnya pada tahun 1996. Sementara itu tiga variabel kontrol dalam persamaan (2) juga signifikan. Perubahan besar earnings per share dan besar dividen per share tahun lalu berpengaruh negatif terhadap probabilitas kenaikan dividen sedangkan besar earnings per share tahun berjalan berpengaruh positif.

Untuk menguji ada tidaknya kesalahan spesifikasi pada model logit di atas digunakan Andrews dan Hosmer-Lemeshow Goodness-of-Fit Tests. Hasil uji menunjukkan bahwa $H$-L Statistic dan Andrews Statistic tidak ada yang signifikan sehingga dapat disimpulkan model di atas tidak mengalami kesalahan spesifikasi. Hasil uji autokorelasi dengan Ljung-Box Q-Satistic juga tidak menemukan adanya masalah autokorelasi dalam model. Untuk menguji robustness dari model di atas, perhitungan koefisien juga dilakukan dengan menggunakan metode iterative selain NewtonRhapson. Dengan metode Quadratic Hill Climbing diperoleh hasil yang sama dengan metode Newton-Rhapson sedangkan dengan metode Berndt-Hall-Hall-Hausman diperoleh hasil koefisien yang lebih tinggi tingkat signifikan negatifnya pada koefisien DFCONT. 


\section{KESIMPULAN DAN SARAN}

Pada tahun 1996, mekanisme bonding dengan meningkatkan hutang secara umum tidak hanya tidak efektif untuk mengurangi masalah agensi bahkan justru menimbulkan peningkatan masalah agensi. Hal ini kemungkinan karena banyak perusahaan yang mengambil hutang dari bank yang masih terkait kepemilikannya dengan pemilik perusahaan sehingga kontrol terhadap penggunaan dana hutang menjadi sangat lemah. Penelitian berikutnya dapat memasukkan variabel sumber hutang sebagai variabel independen untuk menguji benar tidaknya dugaan tersebut. Pada perusahaan yang dikontrol keluarga, efek negatif ini relatif banyak berkurang. Pada tahun 2000, efek negatif meningkatnya hutang terhadap peningkatan masalah agensi sudah dapat dinetralisir dan pada pada perusahaan yang dikontrol keluarga efeknya sudah berubah menjadi positif meskipun efek tersebut belum signifikan. Tidak banyaknya tambahan hutang baru pada tahun 2000 mungkin menjadi penjelas berkurangnya efek negatif tersebut.

Mekanisme bonding dengan meningkatkan dividen secara umum cukup efektif untuk mengurangi masalah agensi. Temuan ini sesuai dengan konsep dasar investasi yang mementingkan kas. Namun tingkat efektifitas bonding dividen antara perusahaan yang dikontrol keluarga dengan perusahaan yang tidak dikontrol keluarga tidak berbeda. Temuan ini memiliki pola yang sama antara tahun 1996 dengan tahun 2000. Dengan demikian investor sebaiknya menuntut dividen yang besar kepada perusahaan publik karena mekanisme ini terbukti efektif untuk mengurangi masalah agensi.

Perusahaan yang porsi kepemilikan keluarganya mendekati batas minimum mayoritas atau dominasi cenderung menghindari mekanisme bonding peningkatan dividen untuk mengurangi masalah agensi. Karena jika pada porsi kepemilikan tersebut perusahaan melakukan peningkatan dividen maka keluarga kemungkinan besar akan kehilangan kekuasaan kontrolnya terhadap perusahaan. Temuan ini memiliki implikasi bahwa investor perlu memperhatikan porsi kepemilikan keluarga -apakah mendekati batas mayoritas/dominasi atau tidak- dalam berinvestasi. 


\section{DAFTAR PUSTAKA}

Barle, A. dan G. Means, (1932), The Modern Corporation and private Property, dalam La Porta, et al (1999), Corporate Ownership Around the World, Journal of Finance, Vol.LIV, No. 2, April.

Claessens S, S. Djankov, dan L. H. P. Lang (2000), The Separation of Ownership and Control in East Asian Corporation, Journal of Financial Economics, Vol. 58 Iss. 1, 2, Oct/Nov. pp 81- 112.

Copeland, E. T dan J. F. Weston, (1992), Financial Theory and Corporate Policy, Third Edition, Addison_Wesley Publishing Company, USA.

Crutchley, E. C., dan R. S. Hansen (1989), A Test of the Agency Theory of managerial Ownership, Corporate Leverage, and Corporate Dividends, Financial Management, Winter, pp 36-46.

EViews 3 User's Guide: Quantitative Micro Software.

Fama, E. H., dan K. R. French (1992), the Cross-Section of Expected Stock Return, the Journal of Finance, Vol. XLVII, No. 2, June, pp 427-465.

Harris, Milton dan A. Raviv (1991), The Theory of Capital Structure, the Journal of Finance, Vol XLVI, No. 1, pp 297 - 355.

Jensen, C. Michael, (1986), Agency Costs of Free Cash Flow, Corporate Finance, and Takeovers, American Economic Review, Vol. 76, No. 2, May.

Jensen, C M dan W. H. Meckling (1976), Theory of the Firm: Managerial Behavior, Agency Costs and Ownership Structure, Journal of Financial Economics No. 3.

Kets de Vies, M. ER, (1993) dalam McConaughy, et al (2001), Founding Family Controlled Firms: Performance, Risk, and Value, Journal of Small Business Management, Milwaukee, January, pp 31 - 49.

Kim, W. S., J. W. Lee, dan J. C. Francis (1988), Investment Performance of Common Stocks in relation to Insider Ownership, The Financial Review, Vol. 23, No. 1, February pp 53- 63.

Kurniawan, M Dudi dan Nur Indriantoro (2000), the Role of Disclosure in Strengthening Corporate Governance and Accountability, The Second Asian Roundtable on Corporate Governance, Hong Kong 31 May - 2 June 2000. 
La Porta, R, F. Lopez-de-Silanes, dan A. Shleifer (1999), Corporate Ownership Around the World, Journal of Finance, Vol.LIV, No. 2, April, pp 471- 517.

McConaughy, L. D., C. H. Matthews, dan A. S. Fialko (2001), Founding Family Controlled Firms: Performance, Risk, and Value, Journal of Small Business Management, Milwaukee, January, pp 31 - 49.

Mitton, Todd, (2002), A Cross-Firm Analysis of the Impact of Corporate Governance on the East Asian Financial Crisis, Journal of Financial Economics, Vol 64, No. 2.

Murali, R dan J.B. Welch, (1989), Agents, Owners, Control and Performance, Journal of Business Finance and Accounting, Summer, pp. 385-398.

Rozeff, Michael S., (1982), dalam Kim et al (1988), Investment Performance of Common Stocks in relation to Insider Ownership, The Financial Review, Vol. 23, No. 1, February pp 53- 63.

Volpin, F Paolo (2002), Governance with Poor Investor Protection: Evidence from Top Executive Turnover in Italy, Journal of Financial Economics, Vol 64, No. 1. 